\title{
Effects of $\mathrm{Rb}$ and $\mathrm{Cs}$ on the Electrogenic Na-pump in Rabbit Sinoatrial Node Cells
}

\author{
Kashima Goto, Tokuyuki TAKAHASHI, Shunichi MiYAMAE, \\ and Shinpei Sudo \\ Department of Physiology, Kanazawa Medical University, \\ Uchinada, Ishikawa, 920-02 Japan
}

\begin{abstract}
The effects of $\mathrm{Rb}$ and $\mathrm{Cs}$ on the electrogenic Na-pump of the rabbit sinoatrial node cell were studied, using conventional microelectrode techniques. Hyperpolarizations induced by $\mathrm{K}$ or its substitutes were recorded from the preparations which were perfused previously with an extracellular K-free solution. The K-induced hyperpolarizations after $\mathrm{K}$-depletion depended linearly on K-concentration in the range of 1.35 to $10.8 \mathrm{~mm}$.

When $2 \mathrm{~mm} \mathrm{Rb}$ was used as an activator, a subthreshold oscillation appeared and the amplitude of the spontaneous action potentials in the $\mathrm{Rb}$ solution was larger than with the standard solution. As the concentration of $\mathrm{Rb}$ increased, the $\mathrm{Rb}$-activated hyperpolarization increased, but the amplitude of the action potential decreased. In the case of Cs, the induced hyperpolarization was smaller than with $\mathrm{K}$ or $\mathrm{Rb}$, and a transient recovery of pacemaker activity and gradual hyperpolarization preceded the true recovery in the standard solution. Since these hyperpolarization effects were not observed after the application of ouabain-containing $\mathrm{K}$-free solution, the hyperpolarizations were considered to be electrogenic. A small hyperpolarization induced by activation of the external site of the Na-pump appears to be necessary for the immediate recovery of automatism from arrest at low resting potentials.
\end{abstract}

Key Words: S-A node, $\mathrm{Rb}, \mathrm{Cs}$ ion, electrogenic pump.

Although there are numerous references available on the electrogenic Na-K pump mechanisms in nerve and muscle cells (KERNAN, 1962; RANG and RITCHIE, 1968; Bolton, 1971; Thomas, 1972; Den Hertog, 1973; Hiraoka and Hecht, 1973; MORITA and KoKETSU, 1979), relatively few experiments have been performed on cardiac preparations. One early observation related to the electrogenic Na-pump was that cardiac arrest occurred on returning isolated frog heart to normal Ringer solution after perfusing with a $\mathrm{K}$-free solution for several minutes (SurawiCZ and GeTtes, 1963). The K-induced hyperpolarization after

Received for publication August 31, 1982

後藤鹿島, 高橋徳之, 宮前俊一, 須藤眞平 
K-free incubation was used as a means of demonstrating the electrogenic $\mathrm{Na}$ pump in various cardiac tissues (NomA and IrISAWA, 1974, 1975; Ellis, 1977; GADSBY and Cranefield, 1979).

Recently, the monovalent cations $\mathrm{Rb}$ and $\mathrm{Cs}$ have been employed instead of $\mathrm{K}$ to reactivate the Na-pump when examining transient increases of hyperpolarization in mammalian ventricular muscle and Purkinje fibers (EISNER and LEDERER, 1979, 1980). Hyperpolarization and recovery from arrest provide a good measure of the degree of reactivation of the external site of the Na-pump. The effect of $\mathrm{Rb}$ is quite similar to that of $\mathrm{K}$, but not the same. Therefore, using Rb and $\mathrm{Cs}$ as substitutes for $\mathrm{K}$, detailed observations were made in the present study of the external site of the Na-pump in sinoatrial (S-A) node cells as compared to the effects of $\mathrm{K}$.

\section{METHODS}

Albino rabbits of either sex, weighing 1.5 to $2.5 \mathrm{~kg}$, were anesthetized with ether. While being ventilated through an endotracheal tube, the thorax was opened and the heart was rapidly removed. A preparation was then made, including the sinus node area, the crista terminalis, and part of the atrial appendage, but without the right atrium. The preparation was trimmed to dimensions of $1 \times 1 \mathrm{~mm}$ for recording the dominant pacemaker potential. It was mounted in a tissue bath of $1 \mathrm{ml}$ volume with its endocardial surface on top. The superfusion fluid contained (in $\mathrm{mM}$ ): $\mathrm{NaCl}, 133 ; \mathrm{KCl}, 5.4 ; \mathrm{CaCl}_{2} \cdot 2 \mathrm{H}_{2} \mathrm{O}, 2.5 ; \mathrm{MgCl}_{2} \cdot 6 \mathrm{H}_{2} \mathrm{O}$, $1.05 ; \mathrm{NaHCO}_{3}, 15 ; \mathrm{Na}_{2} \mathrm{PO}_{4} \cdot 2 \mathrm{H}_{2} \mathrm{O}, 1.2$; and glucose, 5.5 . The $\mathrm{pH}$ was maintained at 7.4 and the temperature, at $36 \pm 0.5^{\circ} \mathrm{C}$. The fluid, oxygenated by gassing with a mixture containing $95 \% \mathrm{O}_{2}$ and $5 \% \mathrm{CO}_{2}$, was led into the bottom of the tissue bath and was suctioned from the surface at a rate of $2 \mathrm{ml} / \mathrm{min}$. Transmembrane potentials were recorded with conventional glass capillary microelectrodes filled with $3 \mathrm{M} \mathrm{KCl}$, whose electrical resistances ranged from 30 to $50 \mathrm{M} \Omega$. The electrodes were coupled via an $\mathrm{Ag}-\mathrm{AgCl}$ wire to an amplifier having high input impedance and capacitance neutralization (MEZ 8261 Nihon-Koden). The output of the amplifier was displayed on an oscilloscope and a recticorder. A modified solution was administered by switching the superfusion fluid from the control to the modified solution. In describing the superfusing solutions, we specify only alternatives to the above standard solution. Thus, a solution described as $10 \mathrm{~mm}$ $\mathrm{Rb}$, is a solution in which all the $\mathrm{K}$ has been removed and $10 \mathrm{~mm} \mathrm{Rb}$ added. When more than $10 \mathrm{~mm}$ was added, the $\mathrm{NaCl}$ was reduced to maintain the tonicity. Control experiments demonstrated that increasing the $\mathrm{NaCl}$ by up to $10 \mathrm{~mm}$ exerted no effect on the membrane potential.

Ouabain (Merck) was made up as a $10 \mathrm{~mm}$ stock in ethanol. The highest concentration of ouabain used was $10^{-5} \mathrm{M}$, the ouabain containing $0.1 \%$ ethanol. We confirmed that this ethanol concentration had no significant effect on potential. 


\section{RESULTS}

In order to observe the processes of recovery of automatism in the sinus node cell, we employed the K-depletion solution by which the automatism was decreased. Initially, we carried out a control experiment in which the electrogenic Na-pump was activated by adding $\mathrm{K}$.

1. $K$-induced hyperpolarization and its process of recovery in the $S$ - $A$ node cell

It should be noted that the entire series in this experiment was run on the same cell. For recording, three kinds of paper speeds were used.

Immediately after K-depletion, the amplitude of the action potentials of the S-A node cell was increased by $4 \mathrm{mV}$ for a few minutes, and gradually decreased thereafter. After $10 \mathrm{~min}$, the action potentials almost disappeared, leaving only small oscillatory potentials (Fig. $1 \mathrm{a}$ and $\mathrm{b}$ ). When standard Tyrode $(\mathrm{K}=5.4 \mathrm{~mm})$ was reintroduced, the membrane hyperpolarized by $18 \mathrm{mV}$, followed by a gradual depolarization for $1.5 \mathrm{~min}$. Complete recovery of spontaneous action potentials was observed within a few minutes. The $\mathrm{K}$-induced hyperpolarization increased as the concentration of $\mathrm{K}$ in the recovery solution increased (Fig. 1b, c, d, and e), their relationship showing a hyperbolic curve (Fig. 7). This K-induced hyperpolarization confirmed the existence of the electrogenic Na-pump observed previously is S-A node cells (NomA and IrISAWA, 1974, 1975) as well as in A-V node cells (KURACHI et al., 1981).

2. Rb-induced hyperpolarization and its process of recovery in the $S$-A node cell

$\mathrm{Rb}$ has been found to substitute for $\mathrm{K}$ in the $\mathrm{K}$ sites of the Na-K pump in Purkinje fibers (EISNER and LEDERER, 1979, 1980). This property of $\mathrm{Rb}$ was examined in the S-A node cell. In Fig. $2 \mathrm{a}, \mathrm{b}$, and d, nodal cells were superfused for $10 \mathrm{~min}$ in K-free solution, and the $5.4 \mathrm{~mm} \mathrm{~K}, 2$ and $4 \mathrm{~mm} \mathrm{Rb}$-induced hyperpolarizations were observed. In the same specimen, higher concentrations of $\mathrm{Rb}$ (10 and $20 \mathrm{~mm} \mathrm{Rb}$ ) were superfused after K-free perfusion (Fig. 3). The hyperpolarization increased as the concentration of $\mathrm{Rb}$ increased, and it appeared to approach a maximum amplitude $(-20 \mathrm{mV})$ at concentrations greater than $10 \mathrm{~mm} \mathrm{Rb}$. The rate of recovery from transient hyperpolarization increased as the concentration of $\mathrm{Rb}$ increased. Spontaneous activities were recovered and maintained in the 2 to $10 \mathrm{mM} \mathrm{Rb}$ solutions, but they ceased within $4.5 \mathrm{~min}$ in the $20 \mathrm{~mm} \mathrm{Rb}$ solution. This suggests that $\mathrm{Rb}$ can substitute for $\mathrm{K}$ within a certain concentration range. The spontaneous activities in the $2 \mathrm{mM} \mathrm{Rb}$ solution revealed a transiently larger amplitude than those in the standard solution (Fig. 2b). In $4 \mathrm{~mm} \mathrm{Rb}$ (Fig. 2d), the transient oscillation was small and the spontaneous activities were almost the same as those for $5.4 \mathrm{~mm} \mathrm{~K}$ solution. The spontaneous activities in the $10 \mathrm{mM} \mathrm{Rb}$ solution were smaller than those for the standard solution. 


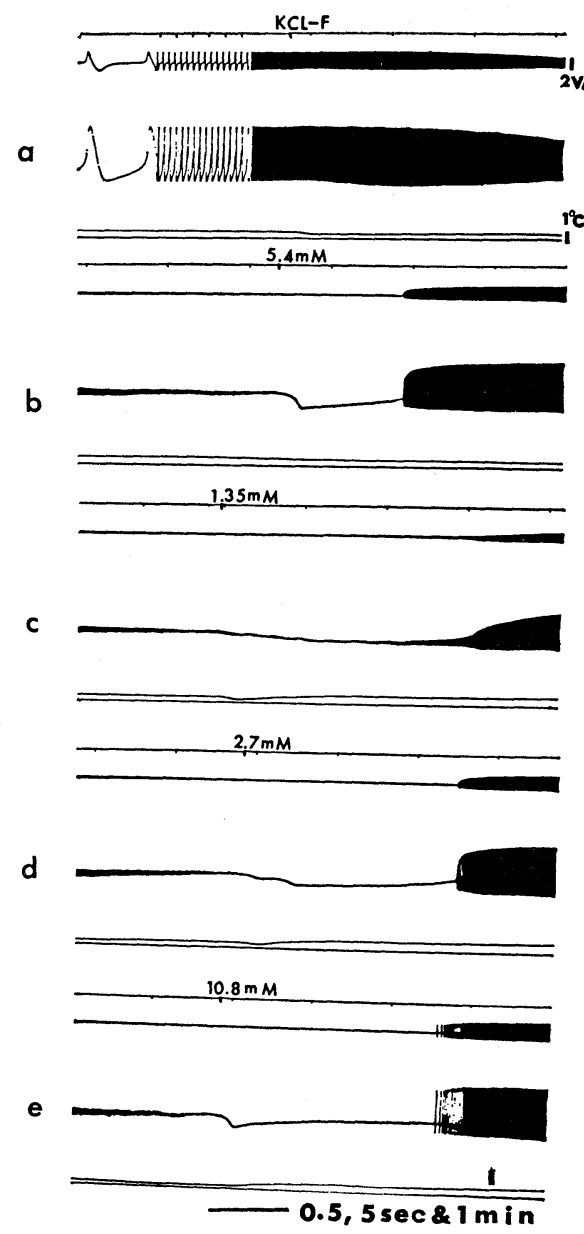

Fig. 1. K-induced hyperpolarizations in the same sinus node cell after exchang of the Kfree solution for the standard one, and different K-concentration Tyrode solutions. a: control of the action potential and depolarization after application of the K-free Tyrode solution. The uppermost panel shows the maximum rate of rise of action potentials $(2 \mathrm{~V} / \mathrm{sec})$. The baseline of the lowermost trace shows the temperature, $35^{\circ} \mathrm{C}$. Vertical bar: $1^{\circ} \mathrm{C}$. b: $10 \mathrm{~min}$ after switching to the $\mathrm{K}$-free solution, the automatic potential almost disappeared and the standard solution $(5.4 \mathrm{~mm})$ was perfused. c: $10 \mathrm{~min}$ after switching to the $\mathrm{K}$-free solution, the potential decreased and the $1.35 \mathrm{~mm} \mathrm{KCl}$ Tyrode solution was perfused. d: $10 \mathrm{~min}$ after switching to the K-free solution, the $2.7 \mathrm{mM}$ $\mathrm{KCl}$ Tyrode was perfused. e: $10 \mathrm{~min}$ after switching to the K-free solution, the $10.8 \mathrm{mM}$ $\mathrm{KCl}$ Tyrode was perfused. Calibration: $20 \mathrm{mV}$. Time scale: 0.5 and $5 \mathrm{sec}$ for the fast record and $1 \mathrm{~min}$ for the slow one. 


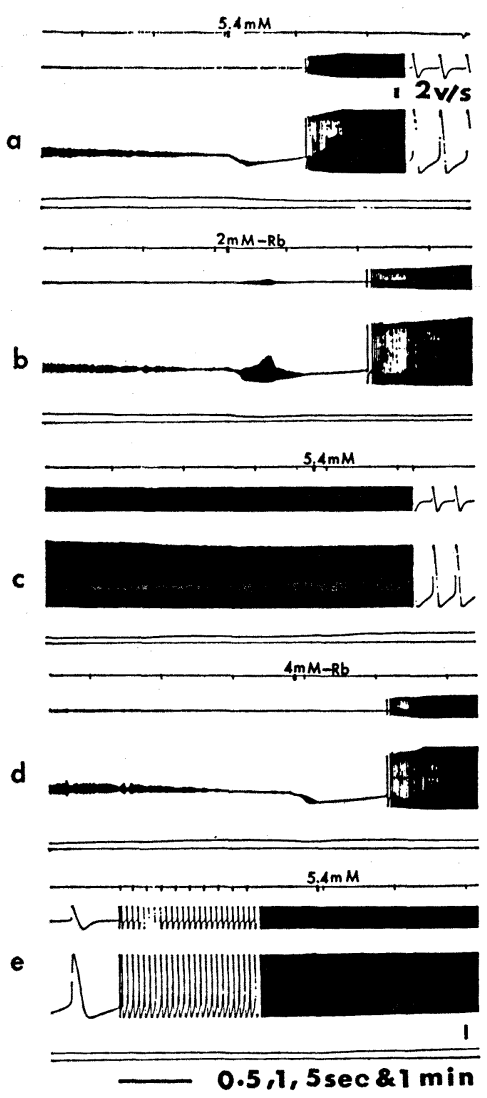

Fig. 2. Rb-induced hyperpolarizations after exchange of the $\mathrm{K}$-free for the 2 and $4 \mathrm{~mm} \mathrm{Rb}$ solution. a: at $5.4 \mathrm{~mm}$, the perfusion was exchanged for the standard solution after $\mathrm{K}$ depletion, as a control for $\mathrm{Rb}$ experiments. $\mathrm{b}$ : $10 \mathrm{~min}$ after application of the $\mathrm{K}$ free solution, the $2 \mathrm{~mm} \mathrm{Rb}$ solution was perfused at $2 \mathrm{~mm} \mathrm{Rb}$. After the exchange there were transient oscillation (triangle), disappearance, depolarization, and reappearance of the action potential. c: at $5.4 \mathrm{~mm}$, the standard solution was perfused. Increased amplitude returned to a normal level before application of the standard solution. $d$ : $10 \mathrm{~min}$ after application of the $\mathrm{K}$-free solution, the $4 \mathrm{mM} \mathrm{Rb}$ was perfused. After switching to the $4 \mathrm{~mm} \mathrm{Rb}$, there occurred a small transient oscillation, disappearance, depolarization, and reappearance of action potential. e: at $5.4 \mathrm{~mm}$, the standard solution was perfused. Amplitude did not change. Calibration: $20 \mathrm{mV}$. Time scale: 0.5 , 1 , and $5 \mathrm{sec}$ for the fast record and $1 \mathrm{~min}$ for the slow one.

\section{Cs-induced hyperpolarization and its process of recovery in the $S$-A node cell}

Figure 4 shows Cs-induced hyperpolarizations after K-depletion, followed by their recovery. Two and $4 \mathrm{~mm}$ Cs solutions were superfused after K-free solution, small hyperpolarizations ( 3 and $4 \mathrm{mV}$, respectively) being observed (Fig. 4b and d). By reintroducing standard K-Tyrode solution (Fig. 4c and e), 


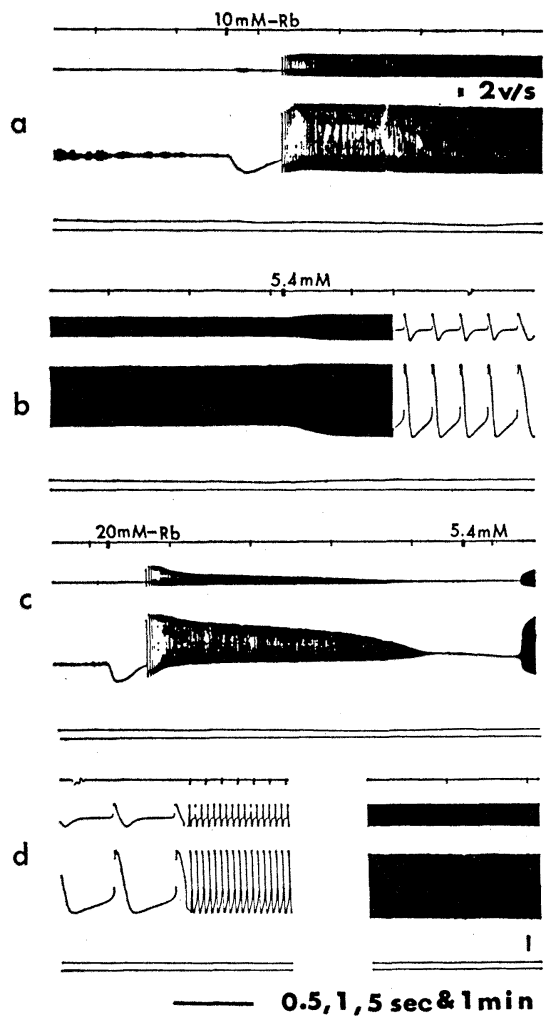

Fig. 3. Ten and $20 \mathrm{~mm} \mathrm{Rb}$-induced hyperpolarizations and their recovery processes. a: $10 \mathrm{~min}$ after application of the K-free solution, the $10 \mathrm{~mm} \mathrm{Rb}$ was perfused. After the exhange of solutions, there were large hyperpolarization, depolarization, and reappearance of action potential. The potential was smaller than that with the standard solution. b: at $5.4 \mathrm{~mm}$, the standard solution was perfused and the amplitude increased. c: $10 \mathrm{~min}$ after application of the $\mathrm{K}$-free solution, the $20 \mathrm{mM} \mathrm{Rb}$ was perfused. After the exchange of solutions, there occurred the largest hyperpolarization, depolarization, and reappearance of action potential. The potential grew smaller and disappeared in $3.5 \mathrm{~min}$. At $5.4 \mathrm{~mm}$, the standard solution was perfused. d: recovery process. Three kinds of time scale were used. Calibration: $20 \mathrm{mV}$. Time scale: $0.5,1$, and $5 \mathrm{sec}$ for the fast record and $1 \mathrm{~min}$ for the slow one.

other small hyperpolarizations were seen, indicating that Cs could not completely substitute for K-induced hyperpolarization. The amplitude of the hyperpolarization increased as the concentration of Cs increased (Fig. 5a and c). In 2 and $4 \mathrm{~mm}$ Cs solutions (Fig. $4 \mathrm{~b}$ and d), small oscillatory potential changes were noted during the period of recovery, whereas in 10 and $20 \mathrm{~mm}$ Cs (Fig. 5), the membrane hyperpolarized and full-blown spontaneous action potentials were observed which lasted 4-1.5 min. These spontaneous action potentials gradually faded away and the resting membrane appeared to be at a slightly depolarized level. 


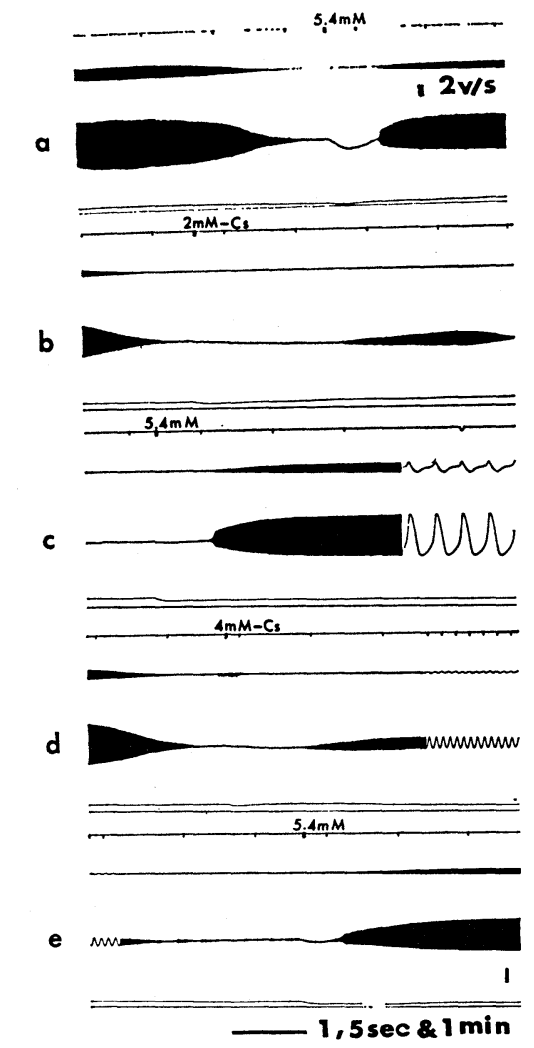

Fig. 4. Cs-induced hyperpolarizations after exchange of the K-free for the 2 and $4 \mathrm{~mm} \mathrm{Cs}$ solution. a: at $5.4 \mathrm{~mm}$, the perfusion was exchanged for the standard solution after the $\mathrm{K}$-depletion, as a control for Cs experiments. b: $10 \mathrm{~min}$ after application of the $\mathrm{K}$ free solution, the $2 \mathrm{~mm}$ Cs was perfused. After the exchange of solutions, there was a small hyperpolarization followed by a transient oscillation. c: at $5.4 \mathrm{~mm}(6 \mathrm{~min}$ after the exchange) the standard solution was perfused. $\mathrm{d}$ : 10 min after application of the $\mathrm{K}$-free solution, the $4 \mathrm{~mm}$ Cs was perfused. After the exchange of solutions, there were small hyperpolarization and transient oscillation. e: at $5.4 \mathrm{~mm}$ the standard solution was perfused. A small hyperpolarization followed by recovery of the action potential was seen. Calibration: $20 \mathrm{mV}$. Time scale: 1 and $5 \mathrm{sec}$ for the fast record and $1 \mathrm{~min}$ for the slow one.

The above experiments indicate that $\mathrm{Cs}$ can also be a substitute for $\mathrm{K}$ sites of $\mathrm{Na}-\mathrm{K}$ pump activity in the membrane. The relation between the hyperpolarization and the concentration of $\mathrm{Cs}$ showed some differences from those observed in $\mathrm{K}$ and in $\mathrm{Rb}$ (Fig. 7A).

\section{Effects of ouabain on Rb-activated hyperpolarization}

Figure 6 illustrates the ouabain inhibition of $4 \mathrm{~mm} \mathrm{Rb}$-activated hyperpolarization in the sinus node cell. In Fig. 6a, application of ouabain K-free solution 


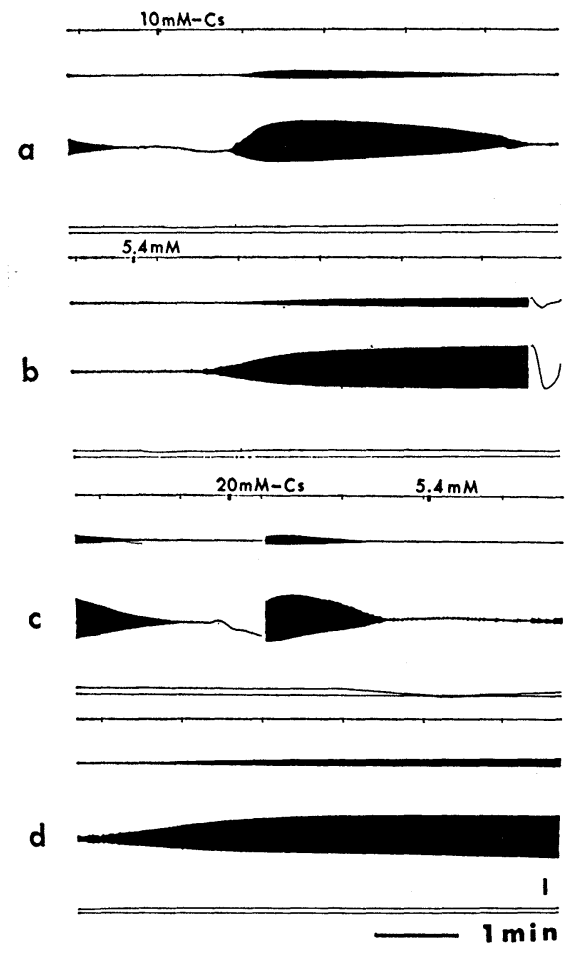

Fig. 5. Ten and $20 \mathrm{~mm}$ Cs-induced hyperpolarizations and their recovery processes. a: 10 min after application of the $\mathrm{K}$-free solution, the $10 \mathrm{~mm}$ Cs was perfused. After the exchange of solutions, there was a small hyperpolarization followed by spontaneous potentials arising from Cs. b: at $5.4 \mathrm{~mm}$ the standard solution was perfused. c: $10 \mathrm{~min}$ after application of the K-free solution, the $20 \mathrm{~mm}$ Cs was perfused. After the exchange of solutions, there was an abrupt hyperpolarization followed by full-blown spontaneous potentials. At $5.4 \mathrm{~mm}$ the standard solution was perfused. d: the process of recovery of the action potentials was seen soon after. Calibration: $20 \mathrm{mV}$. Time scale: $1 \mathrm{~min}$.

after recording of the control pacemaker activity is shown. At $7 \mathrm{~min}$ after the application, this was exchanged for ouabain-free $4 \mathrm{mM} \mathrm{Rb}$ solution (b). There was no Rb-activated hyperpolarization (c). At 9 min after application of the $4 \mathrm{~mm} \mathrm{Rb}$, a small hyperpolarization appeared before the restart of spontaneous activity (d). Almost complete recovery was observed within $30 \mathrm{~min}$, before application of the standard solution (f). It should be noted that little difference in appearance was discernible between the actions of $\mathrm{K}$ and $\mathrm{Rb}$.

\section{Relation between dose and response for $K, R b$, and $C s$}

The diagrams in Fig. 7A and B were constructed from average values obtained from 6-10 experiments. The mean values of the hyperpolarization for $1.35,2.7$, 


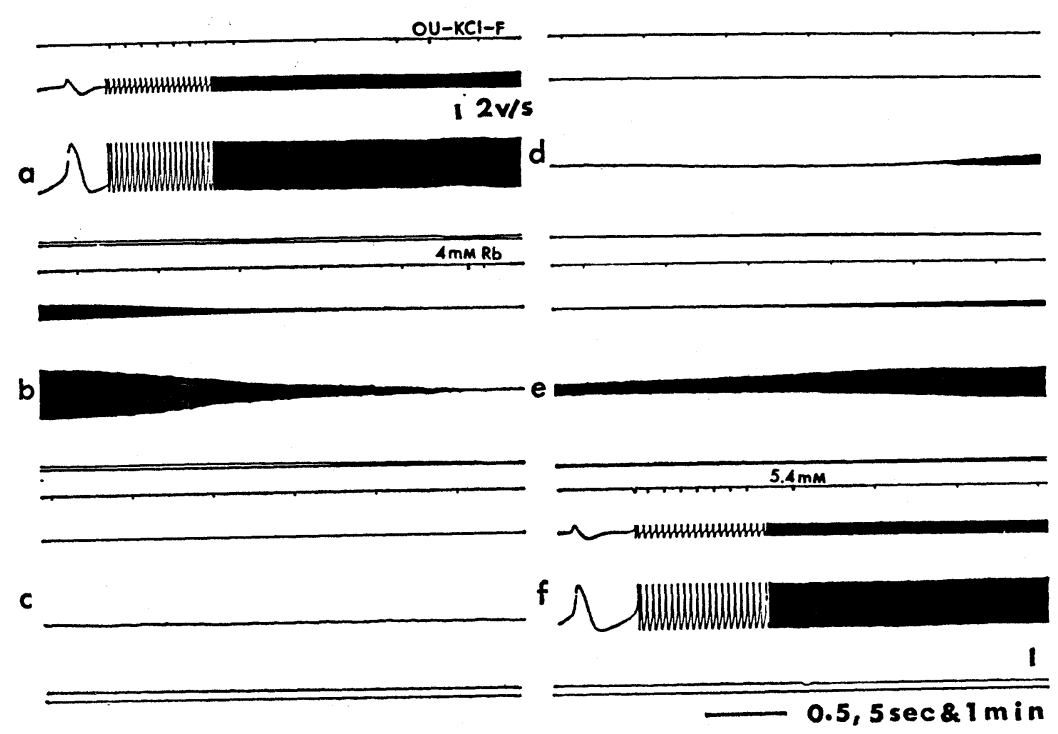

Fig. 6. Effects of ouabain on Rb-activated hyperpolarization. a: control of the pacemaker activity and Ou-KCl-F shows application of the ouabain K-free solution. b: at $4 \mathrm{~mm} \mathrm{Rb} \mathrm{(7} \mathrm{min} \mathrm{after} \mathrm{application} \mathrm{of} \mathrm{ouabain} \mathrm{K}$-free solution) the solution was exchanged for the $4 \mathrm{~mm} \mathrm{Rb}$. c: a quiescent and recovery process. d: a small hyperpolarization $(3 \mathrm{mV})$ is shown. e, f: gradually increasing, and complete reappearance of, potentials in the standard solution (5.4 mM). Calibration: $20 \mathrm{mV}$. Time scale: 0.5 and $5 \mathrm{sec}$ for the fast record and $1 \mathrm{~min}$ for the slow one.

5.4 , and $10.8 \mathrm{mM} \mathrm{KCl}$ were $8,12,18$, and $20 \mathrm{mV}$, respectively. In $\mathrm{Rb}$, the values at $2,4,10$, and $20 \mathrm{~mm}$ ( 6 experiments) were $10,14,20$, and $24 \mathrm{mV}$, respectively. In $\mathrm{Cs}$, the values at $2,4,10$, and $20 \mathrm{~mm}$ (6 experiments) were $3,4,7$, and $20 \mathrm{mV}$, respectively. If the degree of hyperpolarization reflects the activity of the $\mathrm{Na}$ pump at various external $\mathrm{K}, \mathrm{Rb}$, and $\mathrm{Cs}$ concentrations, the kinetics of pump activation by extracellular $\mathrm{K}, \mathrm{Rb}$, and $\mathrm{Cs}$ ions should be obtainable from Lineweaver-Burk plots of the above data. The relation between dose and response appears to be expressed by a hyperbolic curve (Fig. 7A). From these values, the Lineweaver-Burk plots give a straight line, except with Cs. The responses of $\mathrm{K}$ and $\mathrm{Rb}$ have a common regression line, but $\mathrm{Cs}$ yields a rather different one (Fig. 7B).

\section{DISCUSSION}

In Purkinje fibers, based on the ionic theory of membrane potential changes, the mechanism of automatism has been suggested to involve a decrease in the permeability of membrane to $\mathrm{K}^{+}$, an increase in the permeability of membrane to $\mathrm{Na}^{+}$and a reduction in the activity of the electrogenic Na-pump (WeIDMANN, 

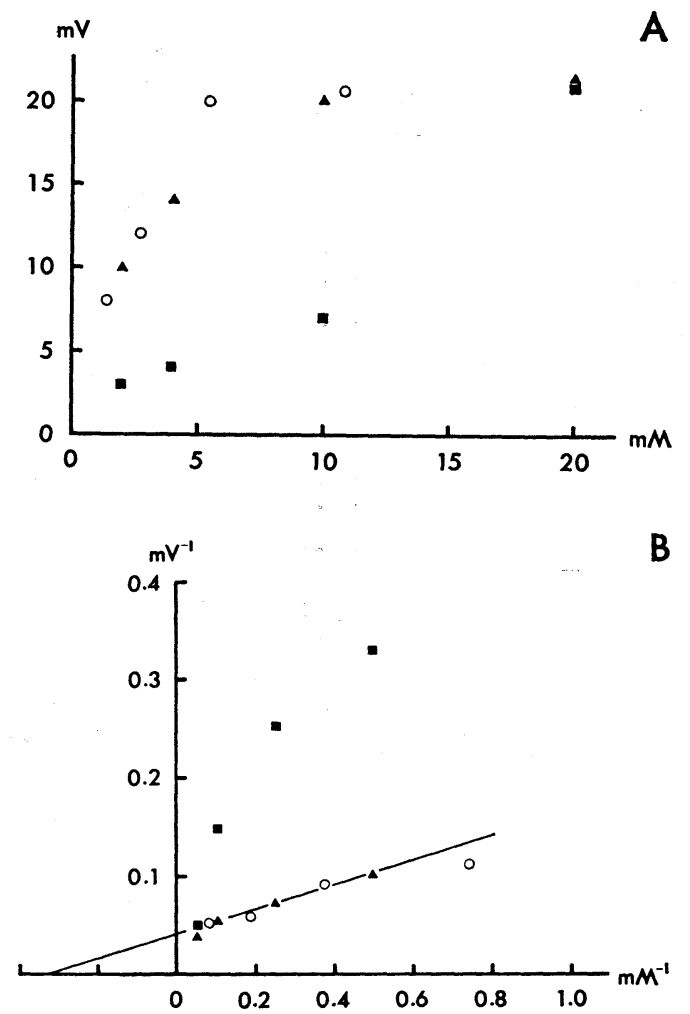

Fig. 7. Relation between dose and response for $\mathrm{K}, \mathrm{Rb}$, and Cs. Diagram A was constructed from average values obtained from 6-10 experiments. A appears to be expressed by a hyperbolic curve in $\mathrm{K}(\mathrm{O})$ and $\mathrm{Rb}(\mathbf{\Lambda})$. From these values a reciprocal plot B shows a straight line, with the exception of Cs $(\mathbf{\square})$. The line of $\mathrm{K}$ resembles the $\mathrm{Rb}$ line very closely.

1956; Brooks and LU, 1972). It has been shown recently that the current system $i_{\mathrm{f}}$ present during the pacemaker depolarization phase in the rabbit sinoatrial node appears as a large inward current slowly yielding hyperpolarizations below -50 to $-60 \mathrm{mV}$ (BRown and Difrancesco, 1980). The latter suggested a possible role of $i_{f}$ in the phase 4 depolarization which is known to overlap the pacemaker range $(-65$ to $-45 \mathrm{mV})$. However, the possible linkage between $i_{\mathrm{f}}$ and the electrogenic pump current has still not been elucidated. EISNER and LEDERER (1980) demonstrated a relationship between the membrane potential and outward current of the electrogenic pump in the Purkinje fiber where $4 \mathrm{mM} \mathrm{KCl}$ was added to the solution bathing a fiber which had previously been exposed to a K-free solution. The membrane was hyperpolarized abruptly from -40 to $-65 \mathrm{mV}$ in $1 \mathrm{~min}$ and gradually depolarized to a somewhat lower level than the original within 5 min. Simultaneously, a transient peak of outward current was observed within 
$60 \mathrm{sec}$, and it then attained an almost steady value by $2.5 \mathrm{~min}$. However, the current did not decrease further. This indicates that there must have been some other background current in this range. In other words, the time course of the current does not parallel the change of voltage.

In our $5.4 \mathrm{mM} \mathrm{KCl}$ experiment (Fig. 1b), the hyperpolarization occurred within $20 \mathrm{sec}$, and the depolarizing time was $1.5 \mathrm{~min}$. The time course depends on the rate of exchange of solution in the bath, but our data were almost compatible with those of Eisner and Lederer.

On the other hand, they reported that the membrane potential in their $20 \mathrm{~mm}$ $\mathrm{Rb}$ experiment changed from -45 to $-80 \mathrm{mV}$ within $15 \mathrm{sec}$, and that the outward current reached a peak within $30 \mathrm{sec}$ and promptly decreased in 2-3 min. In our experiment using $20 \mathrm{~mm} \mathrm{Rb}$, the peak of the hyperpolarization potential appeared within $15 \mathrm{sec}$, and changed from -45 to a maximum of $-70 \mathrm{mV}$. The spontaneous action potentials in the $\mathrm{Rb}$ solution decreased in $3.5 \mathrm{~min}$.

The $\mathrm{Rb}$-induced hyperpolarization and its time course observed in our experiments appear to originate from the outward current of the Na-pump, since they occur in parallel with the change in outward current mentioned. In order to continue the automatism in the presence of $\mathrm{K}, \mathrm{Rb}$, or $\mathrm{Cs}$ after the $\mathrm{K}$-free perfusion, the membrane must retain a certain amount of inward current after the peak of the outward current. Too much inward current such as that after $20 \mathrm{mM} \mathrm{Rb}$, leads to a decrease of repetitive excitation. In $5.4 \mathrm{~mm} \mathrm{~K}$ solution, the outward and inward currents are appropriately balanced.

$\mathrm{Cs}$ shows some differences from $\mathrm{Rb}$ and $\mathrm{K}$. The dose-response curve for Cs is not hyperbolic and the double-reciprocal plot is not a straight line, in contrast to those for $\mathrm{K}$ and $\mathrm{Rb}$ (Fig. 7B). In this case, the Cs-induced hyperpolarization was very small and there was a subthreshold oscillation arising from Cs. Furthermore, K-induced hyperpolarization was noted even after application of normal solution.

According to IsENBERG (1976), Cs acts as a factor blocking the inward rectifying potassium current of the Purkinje fiber. OJEDA et al. (1981) stated that $20 \mathrm{~mm}$ Cs ions reduced the background current and abolished the $\mathrm{K}^{+}$depletion process, probably as a result of elimination of $i_{\mathrm{k}_{1}}$. The specific action of the Cs ion based on our data appears to be correlated with the background current. In order to continue repetitive excitation of the pacemaker cell, the resting potential must remain at a ceratin level so that the outward current is sufficiently maintained, followed by some inward current-not too much, but one which can retain only a subthreshold level. In conclusion, we suggest that a small hyperpolarization followed by some depolarization is necessary for the recovery of automatism in the case of monovalent perfusion which can be correlated with the external site of the Na-pump. 


\section{REFERENCES}

Bolton, T. B. (1971) Electrophysiological evidence of an electrogenic sodium pump in the longitudinal muscle of guinea-pig ileum and its involvement in the response to acetylcholine. J. Physiol. (Lond.), 218: 58-59P.

Brooks, C. McC. and Lu, H. H. (1972) The Sino-atrial Pacemaker of the Heart, Ch. C. Thomas, Spring Field, Ill, pp. 42-67.

Brown, H. and Difrancesco, D. (1980) Voltage-clamp investigation of membrane currents underlying pacemaker activity in rabbit sino-atrial node. J. Physiol. (Lond.), 308: 331-351.

Den Hertog, A. (1973) Some further observations on the electrogenic sodium pump in nonmyelinated nerve fibers. J. Physiol. (Lond.), 231: 493-509.

EISNER, D. A. and Lederer, W. J. (1979) The role of the sodium pump in the effects of potassium depleted solutions on mammalian cardiac muscle. J. Physiol. (Lond.), 294: 273-301.

EISNER, D. A. and Lederer, W. J. (1980) Characterization of the electrogenic sodium pump in cardiac Purkinje fibers. J. Physiol. (Lond.), 303: 441-474.

ELLIS, D. (1977) The effects of external cations and ouabain on the intracellular sodium activity of sheep heart Purkinje fibers. J. Physiol. (Lond.), 273: 211-240.

Gadsby, D. C. and Cranefield, P. F. (1979) Direct measurement of changes in sodium pump current in canine cardiac Purkinje fibers. Proc. Natl. Acad. Sci. U.S.A., 76: 1783-1787.

HiraokA, M. and Неснт, H. H. (1973) Recovery from hypothermia in cardiac Purkinje fibers considerations for an electrogenic mechanism. Pflügers Arch., 339: 25-36.

IsENBERG, G. (1976) Cardiac Purkinje fibers: Cesium as a tool to block inward rectifying potassium currents. Pflügers Arch., 365: 99-106.

KERnAN, R. P. (1962) The role of lactate in the active excretion of sodium by frog muscle. J. Physiol. (Lond.), 162: 129-137.

Kurachi, Y., Noma, A., and IrISAWA, H. (1981) Electrogenic sodium pump in rabbit atrioventricular node cell. Pflügers Arch., 391: 261-266.

MoritA, K. and Koketsu, K. (1979) An analysis of the effect of adrenaline on electrogenic $\mathrm{Na}^{+}$pump of visceral nerve fiber in bullfrogs. Jpn. J. Physiol., 29: 239-250.

Noma, A. and IrISAWA, H. (1974) Electrogenic sodium pump in rabbit sinoatrial node cell. Pflügers Arch., 351 : 177-182.

Noma, A. and IRISAWA, H. (1975) Contribution of an electrogenic sodium pump to the membrane potential in rabbit sinoatrial node cells. Pflügers Arch., 358: 289-301.

OJeDA, C., Rougier, O., and Tourneur, Y. (1981) Effects of Cs on acetylcholine induced current. Is $i_{\mathrm{k}_{1}}$ increased by acetylcholine in frog atrium? Pflügers Arch., 391: 57-59.

RANG, H. P. and RITCHIE, J. M. (1968) On the electrogenic sodium pump in mammalian nonmyelinated nerve fibers and its activation by various external cations. J. Physiol. (Lond.), 196: $183-221$.

Surawicz, B. and GetTes, L. S. (1963) Two mechanisms of cardiac arrest produced by potassium. Circ. Res., 12: 415-421.

Thомаs, R. C. (1972) Electrogenic sodium pump in nerve and muscle cells. Physiol. Rev., 52: $563-594$.

Weidmann, S. (1956) Electrophysiologie der Herzmuskelfaser, Verlag Hans Huber, Bern, pp. $22-45$. 